\title{
A Study on Current Status of Vocal Teaching by View of the Vocal Teaching Papers Summary from Year 2000 to Year 2014
}

\author{
A Case Study of the Core Music Journals
}

\author{
Yu Xiang \\ School Music and Dance \\ Qujing Normal University \\ Qujing, Yunnan, China 655011
}

\begin{abstract}
In the past ten years, the research on vocal teaching has achieved fruitful results. By collecting and sorting out the articles in the core music journals, the author wrote this paper to illustrate what he has found. Namely, the research on vocal teaching focuses on the disciplinary system, mode, reform, theory, pedagogy, selected materials and works of vocal teaching. The psychology, philosophy and skills of vocal teaching are gained the same attention.
\end{abstract}

Keywords—vocal teaching; core; music journals college

\section{INTRODUCTION}

In the first ten years of this century, great achievements on vocal teaching have been made. From the quantitative perspective, explosive growth has occurred in the field of theoretical research. From the quality perspective, the research on vocal teaching is not only unceasingly expanding in breadth and depth but constantly emerging new research viewpoints and fields. Having sorted, generalized and summarized the articles in the core music journals published between 2000 and 2014, this paper studies the current status of vocal teaching.

By searching the core music journals, a total of 148 papers about vocal teaching are found. Among them, four articles are found in People's Music, seventy-three in Chinese Music, eight in Music Research, fourteen in Huang Zhong-Journal of Wuhan Conservatory of Music, China, three in Journal of Central Conservatory of Music, and two in Art of Music and four in Musicology in China. The research direction of this paper is mainly focusing on the following aspects: disciplinary system and mode of vocal teaching, vocal teaching reform, teaching theories, singing pedagogy, selected vocal materials and works, psychology and philosophy of vocal teaching as well as singing skills.

\section{THE GENERALIZATION}

A. The Establishment of Disciplinary System and Mode of Vocal Teaching Plays a Normative Role in Guiding Vocal Teaching in Professional Colleges and Normal Universities

Between 2000 and 2014, there are 16 articles about the establishment of disciplinary system and mode of vocal teaching. Among them, written by Xu Qian and published in People's Music (the eighth issue, 2008), the article named "Crossing Makes New Ways, Vocal Creates Classic Music" -the Study, Practice and Enlightenment on Vocal Theories of Professor Xu Xingxiao has introduced the Vocal Psychology and the Contemporary Vocal Arts and Sciences of professor $\mathrm{Xu}$ in great details. The scientific system of Contemporary Vocal Arts and Sciences is firstly put forward by professor Xu in 1998, the content of which has epoch-making significance in constructing sub-discipline of vocal art and advancing in depth, breadth and multi levels, and in perfecting the discipline of vocal art. The five papers, including the one published in People's Music (November, 2001) by Zhu Xiaoyun and named Discussion on the Creating of Vocal Teaching Lab, the one in People's Music (the eleventh issue, 2006) written by Wang Lina named Study on the Construction of Research-Oriented Learning Mode in Vocal Teaching, the paper published in People's Music (the eighth issue, 2008) by Wang Weiping named Vocal Teaching Should Highlight Modern Music Education Concepts, the one posted in China's Music (the fourth issue, 2009) by Sun Yuemei named the Theory of Establishing a System of National Vocal Teaching and the thesis in People's Music (the eleventh issue, 2010) written by Fu Lin named the M Teaching Method of Popular Vocal Music - the Construction of the Teaching System of Chinese Pop Vocal Music, have respectively studied national vocal teaching system, pop vocal teaching system as well as the theories and mode of vocal teaching. Moreover, the four articles, namely the one by Quan Hui named Preliminary Study on the Vocal Teaching System of Perugia College of Music in Italy, the one published in China's Music (the first issue, 2003) named the System and Tradition of Music Education in Rome St. 
Qieqiliya Conservatory, a Comparison between Chinese and German Vocal Teaching written by Xiao Ping in the People's Music (the twelfth issue, 2008) and On the Current Situation of Vocal Teaching of Russian Genie Music College by Yu Lei published in Huang Zhong (the supplementary issue, 2006), have introduced the vocal teaching system from abroad which provides a reference for the establishment of vocal teaching system in China.

\section{B. The Subject of Vocal Teaching Reform in Normal Universities still Is the Focus of this Period in China}

The current status of vocal teaching in normal universities namely the drawbacks inherited from the mode of professional college, the analysis of background, confusions and hopes in vocal teaching reform, and the feasible suggestions and methods from differing perspectives for vocal teaching reform is discussed in the following articles: the one in People's Music (the second issue, 2000) written by Liu Jiusi and named Creating a New Vocal Teaching System Which Has the Features of Normal Universities; An Experimental Study of Vocal Teaching Pattern Reform-Exploring the Six New Vocal Teaching Modes from Teaching Psychology published in Journal of Central Conservatory of Music (the fourth issue, 2005) by Zheng Maoping; Discussion on the Reform of the Goal and System of Vocal Teaching in Normal Universities in People's Music(the eighth issue, 2005) composed by Yu Hong; the thesis in China's Music (the third issue, 2007) written by Li Shouming and named A Study on Constructing a Scientific and Reasonable Vocal Teaching Mode-Some Hypotheses about Vocal Teaching Reform in Normal Universities; the Vocal Teaching Mode in the New Century by Liu Yuan published in China's Music (the third issue, 2007); and the Vocal Music Teaching Mode Reform Goes forward in Contradiction by Han Tianshou published in People's Music (July, 2011).

\section{For decades, with the Depth of Research on Vocal}

Teaching, a Group of Conception Works of Some

Distinguished Vocal Educators Have Emerged, Which Is of Great Significance

Comparing with the past, there is a trend of increasing articles about the research on the personal theories of vocal teaching. The following list is about the research on educators' vocal teaching theories: in the People's Music (the sixth issue, 2009), Zhao Qing introduced the vocal teaching theories of the Austrian vocal educator, Franz Lukasovsky who is known as the master of German and Austrian art songs; Huang Hao explained the vocal teaching theories of some Italian vocal masters in Huang Zhong(the fourth issue, 2010), such as singing with thinking, singing on the flow of breath, singing by increasing the breath and so on, he also came to the conclusion that the theories is of great importance if they are used in practice; Chen Xiao analyzed the teaching views, principles and methods of professor Hofstede Kai, and studied the ways, skills and ability of works-teaching in Huang Zhong (the fourth issue, 2008), which is a good example for improving the quality of vocal teaching in China; the Dialectical Relationship in the Vocal Teaching of Yu Yixuan by Qiu Yazhou published in China's Music (the third issue, 2009) and the Crystallization of Practice and Wisdom - the Vocal Teaching Theories and Features of $\mathrm{Yu}$ Yixuan published in Journal of Central Conservatory of Music (the fourth issue, 2005) have discussed the vocal teaching theories of the older music educator, Yu Yixuan. In the article named the Research on the Vocal Teaching and Theories of Ying Shangneng, Ren Xiulei elaborated the nationalized vocal theories established by Ying Shangneng through combining the western singing art with the classic of Chinese vocal, and introduced Vocal Directed by Words, which has guiding significance for vocal teaching especially for national vocal. By publishing $A$ Deep Understanding and A Fine Interpretation of the Vocal Teaching Art of Jin Tielin in People's Music (the seventh issue, 2013), Zhou Yong deeply analyzed the Vocal Teaching Art of Jin Tielin, thinking that of fully covering, detailed analysis of philosophy and national features. This rarely seen book has discussed Jin's theories of national vocal teaching and signified the vocal teaching. In A Probe into the Jin Tielin's Theories of National Vocal Teaching, Li Xiaoping illustrated that the essence of national vocal teaching is theoretical practice, focusing on innovation, appropriating methods and true theories. In the Never Say Too Late because of Old AgeA Statement Made in the Seminar Celebrating Zhou Xiaoyan's Sixty-Five Years Dedication to Vocal Teaching in Art of Music (the third issue, 2013), Liu Hui discussed the teaching theories, experience and achievement of professor Zhou.

\section{The Vocal Pedagogy Is One Important Subject of Vocal Teaching Research}

The most representative articles in vocal pedagogy are presented in the following: composed by Zhang Jianguo and printed in People's Music (November, 2011), the Measurement-Weights of the Vocal Teaching in Universities emerged the function of evaluating the vocal teaching, the forms of which include loudness, brightness, thickness, quantity, quality and content in technique, and the span, accuracy, deepness, breadth, profundity and degree in emotion, as well as energy, component, measurement, unbalance, balance and weighting in society. Another article by Zhang published in China's Music (the fifth issue, September, 2010) and named the Constancy and Changes of Vocal Teaching in Normal Universities elaborated some existing problems in vocal teaching from a unique viewpoint. He thought that the constancy in vocal teaching is a genre's holistic pursuit for both standardization in vocal specification and maximization in academic influence. As teachers' idealistic status in passing on the works' style and improving the students' singing ability, the constancy in vocal teaching is also students' spiritual reference for fulfilling the singing requirements and genre norm. While the changes in vocal teaching is not only the genre's competition approach highlighting the professional advantages, but also an effective way in displaying teachers' academic influence, as well as an important platform for showing students' academic achievement within the sight. Zhang holds the opinion that teachers should properly deal with the constancy and change in vocal teaching, such as the constancy and changes in sound specification, mentor-disciple relationship, Cooperative features, concepts and relationship, expansibility like that in material property, library structure and aesthetic ability. By summarizing the features of vocal 
teaching, the article greatly enlightens the vocal teaching and learning. Appeared in China's Music (the second issue, March, 2012 ) by Jiao Chunmei, the Application of Tacit Knowledge to Vocal Teaching in Colleges and Universities puts forward a relatively strange concept-tacit knowledge (contrasting to the explicit knowledge) which namely is hard to systematically express and clearly explained in words, and is sensitive, implicit, image-like and scattered knowledge. The necessity of the existence of tacit knowledge in vocal teaching is highly analyzed in Jiao's article. It is believed that the tacit knowledge exists in the main part, leading the teacher-learner interaction of vocal teaching. The appearance of tacit knowledge contributes to colorizing the pedagogy in class. The Flexible Heuristic Teaching published in China's Music (the second issue, 2013) by Wang Shikui concentrates on the vital functions that the heuristic teaching served in vocal teaching and learning process, which is of great significance in guiding music practice. In the first issue in 2011 of Huang Zhong, Wang Yujian published A Discussion on the Use of Non Vocal-teaching Terms which elaborates the definition, application and the difference and connection of the nonteaching terms in vocal teaching. Printed in Huang Zhong(the third issue, 2011) and authored by Zeng Cheng, On the Three Dialectical Relations in Vocal Teaching of Musical analyzes the characteristics of musical, and explains the unity of voice's stability and style's variety, sounding cavity's stabilization and physical rhythm, as well as interpretation of music's abstraction and songs \& dance's concreteness. The coauthored article named the Feasibility of Applying Computer Visual Audio Parameters to Vocal Teaching by Huang Ying and Yang Jian introduces the trend of international academics namely combining the subject instruction with advanced teaching technology, which includes the recognition of vocal's timbre, volume, force and speed through computer software. Moreover, the articles in People's Music including the Role of Assumption Played in Vocal Teaching by Ding Ruyan in the fifth issue in 2007, Misreading and Rational Thought of Image Thinking in Vocal Teaching by Yu Zizheng in the eleventh issue in 2010, and the Ancient Is Difficult to Sing because of the Spirit - Some Thoughts from the Singing of the Ancient to the Current National Vocal Teaching written by Zhao Yi in the fifth issue in 2012, as well as those in China's Music including the Holistic Consciousness in Vocal Teaching by Zhao Qing in the second issue in 2009, An Analysis of Vague Terms in Vocal Teaching by Li Guangda in the second issue in 2009, the Theoretical Thinking on the Three Relations in Vocal Teaching by Tian Ding in the third issue in 2003, the Practice of Inquiry and Situational Method in Vocal Teaching authored by Wang Bizhu in the third issue in 2004 and the Sound Spectrum Analysis Technology-A Tool of Visualizing Vocal Teaching by Huang Qiang in the fourth issue in 2004, all together study the pedagogy of vocal teaching in differing perspectives.

\section{E. In Vocal Teaching, the Selection of Vocal Materials and Songs Bears Great Significance in the Results of Vocal Teaching}

Therefore, a number of vocal workers make a thorough study on this field. The representative works are introduced in the following. Published by Xu Qian in the sixth issue in 2008 in People's Music, Efforts to Build Material System of China's
Vocal Teaching - the Features and Inspiration of Vocal Teaching Library, which denotes that vocal material is the supporter of the content and mode of vocal teaching, the agency of transforming the thoughts, concepts and purposes to the specific teaching reality, an important tool in achieving the vocal teaching goal. The vocal teaching material serves function in stabilizing the teaching order, referring to foreign vocal culture, prospering the national vocal culture, deepening the reform in the vocal content and promoting the development of vocal teaching. In this article, by analyzing the current status of the editing of vocal teaching materials, $\mathrm{Xu}$ puts forward the idea of building a vocal teaching material library and thinks about the related work of this project. In the Use of Complementary Songs in Vocal Teaching published in People's Music (the ninth issue, 2013), Cao Junling advocates breaking through the limitations of selecting and designing practice in vocal teaching, absorbing nourishment from works of different style, and even using the songs strong different in style but internally related in techniques as complementary ones to practice. In the Difference of Art Songs and Musicals in Vocal Teaching printed in People's Music (the fifth issue, 2009), Su Na points out that the difference of art songs and musicals in sound techniques, singers' roles and performance mode requires teaching plans made according to the objects of works and students. Published in China's Music (the fourth issue, 2006) by Shi Min, Learning from the Kunqu Opera to Promote National Vocal Teaching suggests to regard Kunqu Opera as the breakthrough point for traditional national vocal art to diversify national vocal through the research on such features of Kunqu -the origin of Chinese operas as stressed articulation, rich sound, skilled breath, with emotion as the usher of singing and comprehensive art. What's more, in China's Music, the Application of Shang Deyi's Coloratura Art Songs to Vocal Teaching published in the fourth issue in 2008 by Wei Yijun, the Application of German Art Songs to Vocal Teaching in China printed in the fourth issue in 2003 by Li Ruihua, and the Exploration of Applying Suzhou Pingtan Art to Vocal Teaching published in the fourth issue in 2005 by Shi Min, as well as the Problems in Editing the Materials of National Vocal Teaching published in Art of Music (the second issue, 2008) and the Research on the Songs' Settlement and Related Problems of Vocal Teaching in Normal Universities also do some studies.

\section{F. Among the Papers in Vocal Teaching of the Ten years, the Research from the Crossing Fields Like Psychology and Philosophy Is Abundant}

The psychological activities are of great importance in the process of vocal teaching. From the selected papers in China's Vocal, Crossing Makes New Ways, Vocal Creates Classic Music"-the Study, Practice and Enlightenment on Vocal Theories of Professor Xu Xingxiao published in People's Music (the eleventh issue, 2011) by Xu Qian points out that the psychology of vocal is a specific discipline for establishing vocal art by professor Xu Xingxiao in 1987; in the Effect of Psychological Interaction in Vocal Teaching by Zhou Xiaoyin in the third issue in 2003, the Accumulation and Application of Psychological Knowledge to Vocal Teaching in Normal Universities by Xu Long in the third issue in 2009, the Vocal Teaching Must Emphasize the Research on Psychology 
published in Music Research by Zhang Xiaofa study vocal teaching from different psychological perspectives. The most typical article is the Generation and Control of Students' Negative Emotion in Vocal Teaching published in China's Music (the fourth issue, 2007) by Jiao Chunmei, in which she analyzes the reasons for negative emotion from the teachers and students' perspectives, and affords some measures for preventing and controlling such emotions from the psychological perspective. It is of strong practical significance for the vocal teaching practice.

\section{G. In Recent Years, Discussing the Problems in Vocal Teaching from the Thinking and Ideas of Philosophy Becomes a New Research Direction}

There are four articles published in China's Music, namely Using the Theories of Philosophy in Guiding Vocal Teaching by Wang Shikui in the third issue in 2003, On the Relation between the Partial and Whole in Vocal Teaching by Feng Libin in the fourth issue in 2007, On the Unification of the Quality and Efficiency of Vocal Teaching in Normal Universities by Li Jingyu in the third issue in 2008 and the most representative work published by Peng Lijia in the third issue in 2005 and named A Clever Argument on the Holistic View of Vocal Teaching. In her article, Peng Lijia indicates that it is essential to understand the wholeness of man's vocal organs, the life state of man's articulation, teachers and students, teaching and learning, and the beginning and end as well as the immediate goal of vocal learning and the long-term development of life's quality. And she also emphasizes that vocal teaching should jump out of the single vision centering on training skills which attaches importance to the partial, isolated investigation, being critical, low-level movement and man's singing but makes light of the whole, connected thinking, merits digging, high-level movement and the singing man. Changing the practice of vocalization to the process of adjusting the overall balance in life system and trying to cultivate a vigorous and active life quality are advocated in her article. Moreover, in On the Three Dialectical Relations in Vocal Teaching of Musical published in Huang Zhong (the third issue, 2011), Zeng Cheng indicates that the unity of voice's stability and style's variety, sounding cavity's stabilization and physical rhythm, as well as interpretation of music's abstraction and songs \& dance's concreteness of the new musicals is an effective teaching method for the stage performance in musicals.

\section{CONCLUSION}

The singing skills of vocal music which had been a research field gained much attention declines through the number of papers in the ten years. Thirty articles are in this field, and has rare breakthrough in innovation. However, a small amount of articles emerged to research from a brand new perspective. For instance, the Role of High Pitched Humming Practice in an Open Mouth in the Organ Digital Positioning of Vocal Teaching printed in People's Music (August, 2013) by $\mathrm{Yu}$ Jisheng elaborates the definition of the high pitched humming in an open mouth of the Organ Digital Positioning, analyzes its six advantages and functions by comparing with the traditional humming, and lists the specific practicing methods. By introducing a new concept, this article enriches people's understanding on vocal skills like humming. In Discussion on the Introduction of Yoga Breath to Singing Breath published in China's Music (the second issue, 2013), Lu Yanyu presents the difference between yoga breath and singing breath, and the application of yoga breath to singing. In An Analysis of the Singing Theories in Ancient China and Modern Singing printed in Music Research (the second issue, 2010), Cao Zhangqiong respectively compares the breath, throat opening, sound range and articulation in the ancientsinging theories and the scientific vocal methods. The breath from navel, the development of $\mathrm{Chi}$ and $\mathrm{Li}$, the articulation requirements, the force control and mellow tune play a reference role for advancing the vocal teaching in China.

To sum up the papers in above, the theoretical research of vocal teaching in normal universities has a multi-development different from the oneness of singing skills and songs' performance. The system, mode-establishment and reform of vocal teaching exist with the subject and perfect themselves in development, which makes them the forever research fields. In the process of vocal teaching, it is imperative to generate and introduce the new teaching ideas through time, experience and foreign exchange. The establishment and supplement of the materials and library of vocal teaching will diversify with its development and bring some unique innovation. However, the research fields such as vocal skills and songs' performance does not exclude the interpretation from a brand new perspective.

\section{REFERENCES}

[1] Musicology in China [J]. 2000(1)-2014(4).

[2] Music Research [J]. 2000(1)-2014(6).

[3] China's Music [J]. 2000(1)-2014(4) .

[4] Journal of Central Conservatory of Music [J]. 2000(1)-2014(4).

[5] People's Music [J]. 2000(1)-2014(12).

[6] Huang Zhong (Journal of Wuhan Conservatory of Music, China) [J]. 2000(1)-2014(4).

[7] Art of Music (Journal of the Shanghai Conservatory of Music) [J]. 2000(1)-2014(4) 